\title{
FORMATION AND ROLE OF BACTERIAL COMMUNITY IN THE SEDIMENT BED OF OPEN CHANNEL RECEIVING JOHKASOU EFFLUENT: MULTIVARIATE STATISTICAL ANALYSIS INTERPRETATION
}

\author{
Denny HELARD ${ }^{1,5}$, Joni A. FAJRI ${ }^{1}$, Ahmad S. SETIYAWAN ${ }^{1}$, Fusheng LI $^{2 *}$, Toshiro \\ YAMADA $^{3}$, Akihiro HORIO ${ }^{4}$, Ming $\mathrm{HUANG}^{4}$, Toshiyuki KAWAGUCHI ${ }^{2}$ \\ ${ }^{1}$ Graduate School of Engineering, Gifu University. \\ (1-1 Yanagido, Gifu 501-1193, Japan) \\ ${ }^{2}$ River Basin Research Center, Gifu University. \\ (1-1 Yanagido, Gifu 501-1193, Japan) \\ ${ }^{3}$ Faculty of Engineering, Gifu University. \\ (1-1 Yanagido, Gifu 501-1193, Japan) \\ ${ }^{4}$ Gifu Prefectural Environment Management and Technology Center. \\ (Rokujo Omizo, Gifu 500-8357, Japan) \\ ${ }^{5}$ Department of Environmental Engineering, Faculty of Engineering, Andalas University. \\ (Kampus Limau Manis, Padang 25163, West Sumatera, Indonesia) \\ *E-mail: lifs@gifu-u.ac.jp
}

\begin{abstract}
To obtain information that can be used as reference for improving the environment inside and surrounding the open channels receiving johkasou effluent, the formation and correlation of sediment bed bacterial density with water quality were evaluated with multivariate statistical analysis based on measured data for water and sediment samples collected for 8 times from 6 sites of an open channel that receives johkasou effluent in a residential area of Gifu Prefecture, Japan. Statistical analysis included principal component and factor analysis (PCA/FA), cluster analysis (CA) and correlation analysis. The PCA/FA results showed that 3 dominant factors were responsible for the water quality data structure, accounting for $85.12 \%$ of the total variance in the dataset. Hierarchical cluster analysis grouped 6 study sites into 3 statistically significant clusters, reflecting different characteristics and pollution levels of the sites. Correlation analysis revealed statistically significant relationships of the sediment bed bacterial density with BOD, total nitrogen and total phosphorus in the water of the channel receiving johkasou effluent.
\end{abstract}

Key Words : bacterial density, wastewater, johkasou, sediment, multivariate statistical analysis

\section{INTRODUCTION}

In rural areas where sewerage treatment systems are not available, the small-scale onsite wastewater treatment facility for household wastewater, namely johkasou, has been widely applied in Japan ${ }^{1)}$. There have been more than eight million johkasou installed including tandoku-shori johkasou (67\%, 5.6 million units) and gappei-shori johkasou (33\%, 2.8 million units). Gappei-shori johkasou treats both black and grey water, and is an improvement over tandoku-shori johkasou and serves for about forty million people ${ }^{2}$. The effluent from the johkasou is generally discharged into open channels built within the areas with johkasou installation before it enters the local receiving water bodies. The effluent is essential for maintaining sufficient water in the open channels, enhancing water circulation in the local areas and contributing to the life of aquatic organisms.

After discharged into open channels, the remaining suspended solids (including bacteria) in 
the effluent from the johkasou can settle to the channel bed to form sediment layers. Remaining organic and inorganic nutrients in the effluent can facilitate multiplication of bacterial community in the sediment, with the density of bacteria populated in the sediment getting increased. The formation of bacterial community has the merit to promote self-purification in the channels, but in most cases it leads to enhanced consumption of dissolved oxygen in the shallow water flowing through the channels, thus causing releases of many unpleasant odor-causing substances. Decay of dead bacteria in the sediment is also blamed for water quality and surrounding living environment deteriorations ${ }^{3)}$. In addition, substances occasionally suspended from sediment, for instance during the time of flow rate increases in the open channels, can become sources of contamination for water in the downstream.

Despite the importance of the small onsite wastewater treatment system in the local water cycle and protection of public health, little is known about the quality changes of the effluent after discharged in receiving open channels and the relations with sediment bed bacterial communities, since most investigations conducted so far have focused mainly on the treatment performance of johkasou ${ }^{4-12)}$.

Therefore, the objectives of this study were: (1) to evaluate the formation of sediment bed bacterial community in open channels that receive johkasou effluents and (2) to investigate the possible correlations between sediment bed bacterial density and water quality parameters. These were achieved with the aid of univariate and multivariate statistical analysis of the measurement data for both water and sediment samples from channels receiving johkasou effluent from a residential area in Gifu Prefecture, Japan. The approach of univariate and multivariate statistical analysis is useful for evaluating the relations of water quality with sediment and benthic microbial communities ${ }^{13)}$.

\section{MATERIALS AND METHODS}

\section{(1) Study site and sample collection}

The study site is located in Gifu, Japan, around a residential area where 39 households use Gappei-shori johkasou for treating household wastewater (Fig. 1). Water samples were collected at 6 site points (Site 1 - Site 6) in a $1 \mathrm{~m}$-wide open channel surrounding the residential area (except for Site 4 located at the outlet of a small drainage channel with a width of $35 \mathrm{~cm}$ that receives the effluents from 16 johkasou facilities). Site 1 is located in the outlet of another open channel that is surrounded along its path by paddy fields and receives tandoku-shori johkasou effluents in its upper reach from another residential area. Site 2, located $25 \mathrm{~m}$ away from Site 1, is the confluence of the open channel of Site 1 and another channel receiving gappei-shori johkasou effluents from 23 houses. At the head of this channel, underground water confirmed no existence of either general or heterotrophic bacteria is consistently pumped up and supplied into the channel. Site 3 is located $30 \mathrm{~m}$ downstream of Site 2 and is affected by the effluents from 5 houses that use tandoku-shori johkasou. Site 5 is located in the downstream of the confluence of Site 3 and Site 4 . Site 6 is located in a position $30 \mathrm{~m}$ away from Site 5 and is surrounded by paddy fields along the path from Site 5. Along this $30 \mathrm{~m}$ path, there are no additional johkasou discharge sources.

Samples were collected for eight times in November 2010, December 2010 (hourly sampling), March 2011 (hourly sampling), September 2011 (hourly sampling), October 2011, November 2011, December 2011 and March 2012. Hourly sampling was conducted from 6 am to $12 \mathrm{pm}$ with a time interval of 1 hour. Water samples were collected for $2 \mathrm{~L}$ with polypropylene sampling bottles. Sediment samples were collected as sediment/water mixed liquors, the wet-weight of sediment after settling by centrifugation being around $20-30 \mathrm{~g}$, using a tube with an inner diameter of $30 \mathrm{~cm}$ for Site 1, 2, 3, 5 and 6; and a tube with an inner diameter of $10 \mathrm{~cm}$ for Site 4 since the channel width of this site is small (only $35 \mathrm{~cm}$ ).

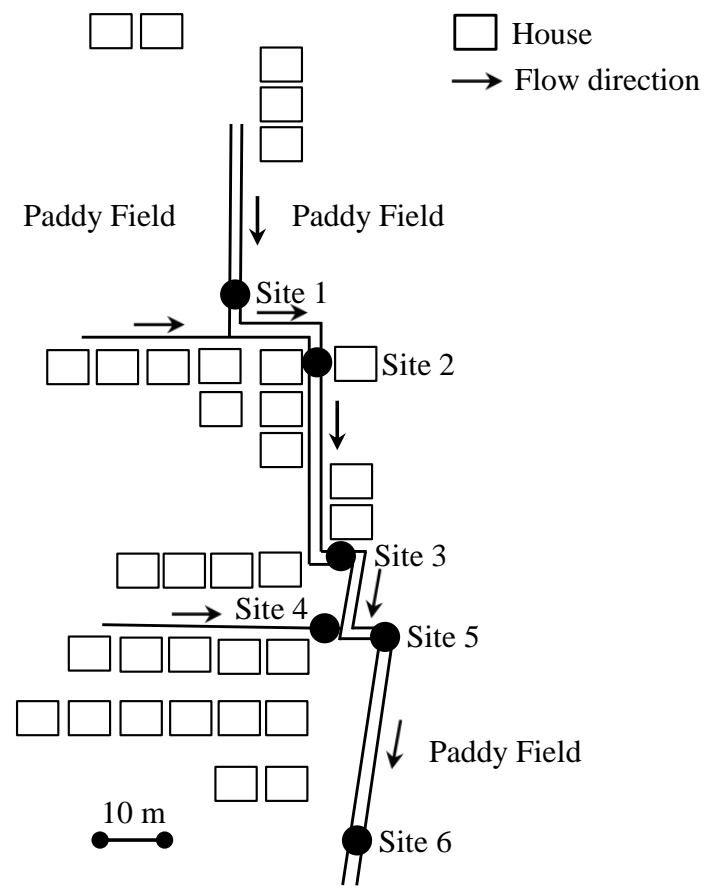

Fig. 1 Residential area and sampling sites of this study (in Gifu, Japan) 
Mixed liquor at each site was collected following the procedures of placing the sampling tube to the bed, detaching the sediment enclosed within the tube into the overlaying water with a brush, and finally collecting the sediment as a mixture of sediment with the overlying water enclosed in the tube. Collected water and sediment samples were stored in cooler box and transported to laboratory for analysis.

\section{(2) Analytical methods}

For sediment samples, three parameters, namely total solids (TS), heterotrophic bacteria (referred as HPC_S) and DNA-based bacterial density (referred as DNA_S), were analyzed. For water samples, pH, water temperature (Temp), electrical conductivity (EC), ultraviolet absorbance at 260nm (UV260), dissolved oxygen (DO), chemical oxygen demand (COD), biochemical oxygen demand (BOD), total nitrogen (TN), total phosphorus (TP) and chloride ion were analyzed. Flow rate in the channels was measured during sampling together with Tempt, $\mathrm{pH}$, DO and EC. Table 1 summarizes the methods of analysis for all sediment and water parameters.

Heterotrophic bacteria. Heterotrophic bacteria were analyzed based on standard plate count method (9215A) using TGYE (tryptose glucose yeast extract) as the culture medium ${ }^{14)}$. The incubation time was 7 days and the temperature was $20^{\circ} \mathrm{C}$.

DNA-based bacterial density. A given quantity of sediment was subjected to DNA extraction using Power Soil ${ }^{\mathrm{TM}}$ DNA isolation kit (MO BIO Lab. Inc., $\mathrm{CA})$ according to manufacturer's instructions. The extracted DNA was stored frozen at $-20^{\circ} \mathrm{C}$ prior to quantification with the real-time PCR. The calibration curve was obtained using DNA extracted from E. coli, Escherichia coli $\mathrm{K}-12 \mathrm{~F}^{+}$(No. 13965, NITE Biological Resource Center, Japan $)^{15)}$, the concentration of which was determined with the NanoVue $^{\text {TM }}$ UV/Visible Spectrophotometer (GE Company). A diluted series of known E.coli DNA concentrations $(10,1,0.1,0.01,0.001$ and 0.0001 $\mathrm{ng} / \mu \mathrm{L}$ ) was used for the calibration curve. E.coli was well used as the standard for determination of bacterial DNA concentrations by real-time PCR ${ }^{16-18)}$. Quantification was carried out using Thermal Cycler Dice $^{\mathrm{TM}}$ Real Time System TP800 (Takara Bio Inc.) and SYBR ${ }^{\circledR}$ Premix Ex Taq ${ }^{\text {TM }}$ (Takara Bio Inc.), following the instruction manual from the manufacturer. Universal primers, com1 (5'-CAG CAG CCG CGG TAA TAC-3') and com2 (5'-CCG TCA ATT CCT TTG AGT TT-3'), were used for PCR amplification of $16 \mathrm{~S}$ rDNA ${ }^{15},{ }^{19}$ ). DNA extracted from samples and the diluted DNA series of $E$. coli were prepared as templates. The solution of PCR reaction $(25 \mu \mathrm{L})$ contained $0.5 \mu \mathrm{L}$ of each primer $(10 \mu \mathrm{M}), 2 \mu \mathrm{L}$ of template and $12.5 \mu \mathrm{L}$ of $\mathrm{SYBR}^{\circledR}$ Premix Ex $\mathrm{Taq}^{\mathrm{TM}}$ and $9.5 \mu \mathrm{L}$ of pure water. Amplification of the 16S rDNA followed the 2 step PCR protocol: initial denaturation at $95^{\circ} \mathrm{C}$ for $30 \mathrm{sec}$, followed by 40 cycles of denaturation at $95^{\circ} \mathrm{C}$ for 5 sec and annealing at $60{ }^{\circ} \mathrm{C}$ for $30 \mathrm{sec}$. All samples were performed in triplicates.

Bacterial community structure. For investigating bacterial community structure, the extracted DNA from samples was amplified with the same Thermal Cycler Dice ${ }^{\mathrm{TM}}$ Real Time System TP800 (Takara Bio Inc.) using the primer set of GC-341f/907r (GC-341f: GC clamp 5'-CGC CCG CCG CGC GCG GCG GGC GGG GCG GGG GCA CGG GGG G-3' attached on the 5'-end of the 341f: 5'-CCT ACG GGA GGC AGC AG-3'; 907r: 5'-GTA GTT TCG TGG ATG CCA CA-3' ${ }^{20-22)}$. This primer set is capable of amplifying most bacteria from sediment samples ${ }^{23)}$. The $50 \mu \mathrm{L}$ PCR reaction mixture contained $0.5 \mu \mathrm{L}$ of each primer $(25 \mu \mathrm{M}), 1 \mu \mathrm{L}$ of template, $0.25 \mu \mathrm{L}$ of Ex Taq $^{\mathrm{TM}}$ enzyme $(250 \mu \mathrm{M}), 5 \mu \mathrm{L}$ of $10 \mathrm{x} \mathrm{Ex} \mathrm{Taq}^{\mathrm{TM}}$ buffer, $4 \mu \mathrm{L}$ of dNTPs $(2.5 \mathrm{mM}), 1 \mu \mathrm{L}$ of Bovine serum albumin (BSA, 1\%) and $37.5 \mu \mathrm{L}$ of pure water. Thermal cycling for the initial amplification was carried out by an initial denaturation step at $95^{\circ} \mathrm{C}$ for $3.5 \mathrm{~min}$, followed by 35 cycles of denaturation step at $95{ }^{\circ} \mathrm{C}$ for $30 \mathrm{~s}$, annealing at $57{ }^{\circ} \mathrm{C}$ for $30 \mathrm{~s}$ and extension at $72{ }^{\circ} \mathrm{C}$ for $40 \mathrm{~s}$. Cycling was completed by a final extension step at $72{ }^{\circ} \mathrm{C}$ for $10 \mathrm{~min}$. All samples were performed in triplicates. DGGE was performed with the DCode System (Bio-Rad, USA). PCR products were loaded onto $10 \%$ (w/v) polyacrylamide gel in $1 \times \mathrm{TAE}$ buffer $(20 \mathrm{mmol} / \mathrm{L}$ Tris, $10 \mathrm{mmol} / \mathrm{L}$ acetate, $0.5 \mathrm{mmol} / \mathrm{L}$ EDTA (pH 7.4)). The $10 \%(\mathrm{w} / \mathrm{v})$ polyacrylamide gel (bisacrylamide : acrylamide $=37.5: 1$ ) was made with a denaturing gradient ranging from 30 to $60 \%$ (where $100 \%$ denaturant contains $7 \mathrm{~mol} / \mathrm{L}$ urea and $40 \%$ formamide). Electrophoresis was run at $60^{\circ} \mathrm{C}$ and 80 $\mathrm{V}$ for 12 hours. After electrophoresis, the gels were stained for $15 \mathrm{~min}$ with ethidium bromide and photographed on a UV trans-illumination table with the Gel Documentation Systems (Bio-Rad, USA).

Conventional water quality parameters. Temperature, $\mathrm{pH}, \mathrm{EC}$ and $\mathrm{DO}$ were measured directly at each sampling site with corresponding potable meters (DKK-TOA, Japan). UV260, BOD, $\mathrm{TN}, \mathrm{TP}$ and Chloride ion were analyzed according to the standard methods ${ }^{24)}$.

\section{(3) Data preparation and statistical analysis}

Measurement data were subjected to univariate analysis (range, mean and standard deviation) and multivariate analysis (Principal Component /Factor Analysis (PCA/FA) and Cluster Analysis (CA)). 
Table 1 Sediment and water quality parameters, units and analytical methods

\begin{tabular}{|c|c|c|c|}
\hline Parameter & Abbreviation & Analytical method & Unit \\
\hline \multicolumn{4}{|l|}{ Sediment } \\
\hline Total solids & $\mathrm{TS}$ & Drying at $105{ }^{\circ} \mathrm{C} /$ weighing & $\mathrm{mg} / \mathrm{cm}^{2}$ \\
\hline Heterotrophic plate count bacteria & HPC_S & Plate count method & $\mathrm{CFU} / \mathrm{cm}^{2}$ \\
\hline DNA-based bacteria & DNA_S & Real-time PCR & cells $/ \mathrm{cm}^{2}$ \\
\hline \multicolumn{4}{|l|}{ Water } \\
\hline$\overline{\text { Flow rate }}$ & Flow rate & Electrical device & $\mathrm{L} / \mathrm{s}$ \\
\hline $\mathrm{pH}$ & $\mathrm{pH}$ & Potentiometry/pH probe & $\mathrm{pH}$ units \\
\hline Water temperature & Temp & Temperature probe & ${ }^{\mathrm{O}} \mathrm{C}$ \\
\hline Electrical conductivity & $\mathrm{EC}$ & Conductometry & $\mathrm{mS} / \mathrm{m}$ \\
\hline Oxidation-reduction potential & ORP & Potentiometry/ORP probe & $\mathrm{mV}$ \\
\hline Ultraviolet absorbent at $260 \mu \mathrm{m}$ & UV260 & Spectrophotometry & $1 / \mathrm{m}$ \\
\hline Suspended solids & SS & Drying at $105{ }^{\circ} \mathrm{C} /$ weighing & $\mathrm{mg} / \mathrm{L}$ \\
\hline Dissolved oxygen & DO & Potentiometry $/ \mathrm{O}_{2}$ probe & $\mathrm{mg} / \mathrm{L}$ \\
\hline Biochemical oxygen demand & BOD & Winkler azide method & $\mathrm{mg} / \mathrm{L}$ \\
\hline Total nitrogen & $\mathrm{TN}$ & Kjeldahl method & $\mathrm{mg} / \mathrm{L}$ \\
\hline Total phosphorus & $\mathrm{TP}$ & Ascorbic acid method & $\mathrm{mg} / \mathrm{L}$ \\
\hline Chloride & Chloride & Ion chromatography & $\mathrm{mg} / \mathrm{L}$ \\
\hline Heterotrophic plate count bacteria & HPC_W & Plate count method & $\mathrm{CFU} / \mathrm{mL}$ \\
\hline DNA-based bacteria & DNA_W & Real-time PCR & cells/mL \\
\hline
\end{tabular}

Prior to such analyses, the Kolmogorov-Smirnov (K-S) test was used to evaluate the goodness-of-fit of the data to log-normal distribution ${ }^{25)}$. According to the K-S test, all the parameters are log-normally distributed with significance levels of 0.05 or lower.

To examine the suitability of the data for principal component analysis, Kaiser-Meyer-Olkin (KMO) and Barlett's tests were performed. KMO is the measurement of sampling adequacy, showing the proportion of variance which is common variance ${ }^{25)}$. High value (close to 1) generally suggests that the principal component/factor analysis is useful. For this study, the value of KMO is 0.838 .

Barlett's test of sphericity indicates whether the correlation matrix is an identity matrix, which indicates that variables are unrelated ${ }^{25}$. The significance level of less than 0.001 in this study suggests that there are significant relationships among parameters.

PCA/FA analysis is a multivariate statistical analysis used to identify important components or factors that explain most of the variances of a system ${ }^{26}$.

Cluster analysis (CA) is a group of multivariate techniques whose primary purpose is to assemble objects based on the characteristics they possess. The resulting clusters of objects should then exhibit high internal (within-clusters) homogeneity and high external (between clusters) heterogeneity ${ }^{25)}$. In this study, hierarchical agglomerative CA was performed on the normalized data set by means of the Ward's method using Euclidean distances as a measurement of the similarity to obtain dendrograms, and sampling sites in the same category are considered to have similar pollutant sources ${ }^{25,27)}$. Cluster analysis was used in the present study because a visual summary of intra-relationship amongst various parameters can lead to a better understanding of the governing factors.

Correlation analysis was performed using the non-parametric Spearman's rank correlation as not to assume normality of any of the parameters ${ }^{25}$.

16S PCR-DGGE analysis was used to obtain patterns of bacterial community and trace the changes of bacterial community in the sites. Based on the presence (1) or absence (0) of individual bands in each lane, a binary matrix was constructed. The binary data representing the banding patterns were used to generate a pairwise Dice distance matrix. A dendrogram was obtained by unweighted pair group mean average (UPGMA) cluster analysis ${ }^{28)}$.

All mathematical statistical analysis was conducted using Microsoft Office Excel 2010 and IBM $^{\circledR}$ SPSS $^{\circledR}$ Statistic version 20.

\section{RESULTS AND DISCUSSION}

\section{(1) Bacterial density in sediment bed}

Table 2 summarizes the measurement results (including the range, mean value and standard deviation) for samples of all 6 sampling sites. In order to precisely present their special characteristics, Box and whisker plots are also provided.

As shown in Fig. 2, bacterial parameters (HPC_S and DNA_S) of sediment bed revealed spatial variations in the channels. The mean concentrations of HPC_S and DNA_S ranged from $2.5 \times 10^{7}$ (Site 6) to $1.8 \times 10^{8} \mathrm{CFU} / \mathrm{cm}^{2}$ (Site 4) and from $5.6 \times 10^{8}$ (Site 5) to $5.7 \times 10^{10}$ cells $/ \mathrm{cm}^{2}$ (Site 4), respectively. Meanwhile, the mean concentrations of total solid 
(TS) in the sediment bed ranged from 9.5 (Site 5) to $187.1 \mathrm{mg} / \mathrm{cm}^{2}$ (Site 1). The DNA_S was slightly but significantly correlated with HPC_S and TS $(r=0.364$ and 0.571 with $p<0.05$ and $<0.01$, respectively), but no significant correlation was obtained between HPC_S and TS $(r=0.124, p=0.477)$.

Site 4 had the highest heterotrophic bacterial loadings than other sites. Since this site received only johkasou effluent, different from other sites that are also affected by surrounding paddy fields and underground water, the results of this site may better reflect the bacterial characteristics of sediment in the channel receiving johkasou effluent.

\section{(2) Water quality parameters}

Fig. 3 shows the box and whisker plots for the water quality parameters $\mathrm{DO}, \mathrm{BOD}, \mathrm{TN}$ and $\mathrm{TP}$. The broader variation range of the measured values at each site suggests the presence of temporal variations caused likely by polluting sources and/or climatic factors. The lowest level of DO and the highest levels of BOD, TN and TP were found with Site 4. This is due to the fact mentioned earlier that this site receives only johkasou effluent and there is not any dilution effect from paddy fields and underground water as other sites could expect.

Table 2 Measurement results for sediment and water quality parameters at all sampling sites during the period of the study

\begin{tabular}{|c|c|c|c|c|c|c|}
\hline \multirow[t]{2}{*}{ VARIABLE } & \multicolumn{6}{|c|}{ Study Site } \\
\hline & Site 1 & Site 2 & Site 3 & Site 4 & Site 5 & Site 6 \\
\hline \multicolumn{7}{|l|}{ Sediment } \\
\hline \multirow[t]{2}{*}{ TS $\left(\mathrm{mg} / \mathrm{cm}^{2}\right)$} & 46.4-634.2 (6)* & $38.1-114.0(5)$ & $31.0-75.0(6)$ & $4.3-438.4(6)$ & $5.4-15.8(6)$ & $24.3-90.5(6)$ \\
\hline & $187.1(224.2)^{* * *}$ & $68.6(30.5)$ & $48.1(16.9)$ & $91.0(170.6)$ & $9.5(3.9)$ & $50.8(25.1)$ \\
\hline \multirow[t]{2}{*}{ HPC_S (CFU/ $\left.\mathrm{cm}^{2}\right)$} & $8.1 \times 10^{4}-5.2 \times 10^{8}(7)$ & $2.9 \times 10^{6}-7.9 \times 10^{8}(5)$ & $6.5 \times 10^{5}-6.5 \times 10^{8}(6)$ & $2.7 \times 10^{6}-5.4 \times 10^{8}(7)$ & $3.0 \times 10^{6}-2.1 \times 10^{8}(6)$ & $3.6 \times 10^{5}-1.1 \times 10^{8}(7)$ \\
\hline & $8.5 \times 10^{7}\left(1.9 \times 10^{8}\right)$ & $1.7 \times 10^{8}\left(3.5 \times 10^{8}\right)$ & $1.1 \times 10^{8}\left(2.6 \times 10^{8}\right)$ & $1.8 \times 10^{8}\left(2.0 \times 10^{8}\right)$ & $4.7 \times 10^{7}\left(8.2 \times 10^{7}\right)$ & $2.5 \times 10^{7}\left(3.8 \times 10^{7}\right)$ \\
\hline \multirow[t]{2}{*}{ DNA_S (cells/cm²) } & $2.3 \times 10^{8}-3.0 \times 10^{10}(7)$ & $8.1 \times 10^{7}-3.8 \times 10^{9}(5)$ & $5.6 \times 10^{7}-5.7 \times 10^{9}(6)$ & $1.7 \times 10^{8}-3.9 \times 10^{11}(7)$ & $1.0 \times 10^{7}-2.6 \times 10^{9}(6)$ & $9.9 \times 10^{7}-5.2 \times 10^{9}(7)$ \\
\hline & $4.6 \times 10^{9}\left(1.1 \times 10^{10}\right)$ & $1.1 \times 10^{9}\left(1.5 \times 10^{9}\right)$ & $1.1 \times 10^{9}\left(2.3 \times 10^{9}\right)$ & $5.7 \times 10^{10}\left(1.5 \times 10^{11}\right)$ & $5.6 \times 10^{8}\left(1.1 \times 10^{9}\right)$ & $1.3 \times 10^{9}\left(1.9 \times 10^{9}\right)$ \\
\hline \multicolumn{7}{|l|}{ Water } \\
\hline \multirow[t]{2}{*}{$\overline{\text { Flowrate }(L / s)}$} & $0.86-34.19(35)$ & $4.0-37.84(9)$ & $3.3-35.53(29)$ & $0.05-1.31(52)$ & $2.47-42.97(27)$ & $4.71-61.66(34)$ \\
\hline & $14.79(10.69)$ & $17.31(10.13)$ & $17.72(9.97)$ & $0.30(0.25)$ & $19.79(11.63)$ & $26.5(12.53)$ \\
\hline \multirow[t]{2}{*}{ pH } & $7.1-8.8(57)$ & $7.2-7.9(10)$ & $7.1-8.0(33)$ & $7.0-7.7(53)$ & $7.1-8.0(32)$ & $7.0-7.9(36)$ \\
\hline & $7.5(0.33)$ & $7.5(0.21)$ & $7.3(0.19)$ & $7.4(0.17)$ & $7.3(0.22)$ & $7.4(0.24)$ \\
\hline \multirow[t]{2}{*}{ Temp $\left({ }^{\circ} \mathrm{C}\right)$} & 7.6-27.2 (33) & $10.6-26.2(7)$ & $10.7-28.5(30)$ & $10.5-28.6(50)$ & $10.6-27.6(29)$ & $10.5-28.1(33)$ \\
\hline & $18.6(6.27)$ & $15.0(5.11)$ & $19.4(5.54)$ & $18.9(7.13)$ & $19.2(5.42)$ & $18.5(5.94)$ \\
\hline \multirow[t]{2}{*}{$\mathbf{E C}(\mathrm{mS} / \mathrm{m})$} & $10.7-37.0(57)$ & $12.7-17.0(9)$ & $11.9-37.8(33)$ & $15.3-50.0(53)$ & $12.0-24.0(32)$ & $11.7-23.0(36)$ \\
\hline & $18.1(8.5)$ & $14.5(1.51)$ & $14.6(4.6)$ & $39.8(6.31)$ & $14.9(3.24)$ & $14.5(3.06)$ \\
\hline \multirow{2}{*}{ ORP (mV) } & $44-243(33)$ & $66-222(7)$ & $42-250(30)$ & $131-244(50)$ & $42-208(29)$ & $51-241(33)$ \\
\hline & $127(49)$ & $136(55)$ & $129(49)$ & $165(26)$ & $134(48)$ & $153(42)$ \\
\hline \multirow[t]{2}{*}{$\mathrm{UV}_{260}(1 / \mathrm{m})$} & $0.52-8.12(21)$ & $0.45-1.22(6)$ & $0.45-3.35(22)$ & $0.75-12.19(42)$ & $0.44-4.71(21)$ & $0.52-4.63(20)$ \\
\hline & $2.11(2.16)$ & $0.69(0.26)$ & $1.15(0.9)$ & $7.17(4.13)$ & $1.30(1.28)$ & $1.48(1.15)$ \\
\hline \multirow[t]{2}{*}{ SS (mg/L) } & $0.3-26.5$ (44) & $1.0-24.5(10)$ & $0.2-24.0(25)$ & $0.2-26.2(44)$ & $0.2-19.8(24)$ & $0.2-13.6(22)$ \\
\hline & $6.4(6.1)$ & $4.2(7.3)$ & $6.6(6.5)$ & $3.3(4.5)$ & $6.2(5.7)$ & $4.9(4.6)$ \\
\hline \multirow[t]{2}{*}{ DO $(\mathrm{mg} / \mathrm{L})$} & $5.35-7.48(21)$ & $5.81-7.01(6)$ & 5.34-7.31 (21) & $2.48-4.4(21)$ & $5.02-7.15(20)$ & $5.19-7.32(20)$ \\
\hline & $6.36(0.59)$ & $6.35(0.61)$ & $6.33(0.54)$ & $3.33(0.46)$ & $6.14(0.57)$ & $6.19(0.55)$ \\
\hline \multirow[t]{2}{*}{ BOD (mg/L) } & $0.6-12.0(33)$ & $0.6-1.9(6)$ & $0.59-17.0(15)$ & $4.9-28(28)$ & $1.1-6.8(14)$ & $1.0-6.9(12)$ \\
\hline & $4.04(3.80)$ & $1.33(0.44)$ & $2.63(4.01)$ & $11.42(5.12)$ & $2.59(1.73)$ & $2.68(2.09)$ \\
\hline \multirow[t]{2}{*}{ TN (mg/L) } & $0.40-6.80(37)$ & $0.70-2.50(10)$ & $0.58-2.94(19)$ & $1.57-24.0(32)$ & $0.73-5.20(18)$ & $0.61-6.10(16)$ \\
\hline & $2.76(2.04)$ & $1.45(0.57)$ & $1.57(0.79)$ & $16.28(4.69)$ & $2.38(1.56)$ & $2.34(1.63)$ \\
\hline \multirow[t]{2}{*}{$\mathbf{T P}(\mathrm{mg} / \mathrm{L})$} & $0.08-0.84(33)$ & $0.10-0.32(6)$ & $0.11-0.43(15)$ & $0.83-3.20(28)$ & $0.12-0.73(14)$ & $0.10-0.77(12)$ \\
\hline & $0.34(0.25)$ & $0.19(0.08)$ & $0.22(0.1)$ & $2.03(0.46)$ & $0.32(0.21)$ & $0.28(0.21)$ \\
\hline \multirow[t]{2}{*}{ Chloride (mg/L) } & $2.8-28.0(32)$ & $4.9-8.9(6)$ & $3.0-11.0(15)$ & $11.0-29.0(28)$ & $3.2-14.0(14)$ & $2.90-12.0(12)$ \\
\hline & $10.57(7.52)$ & $6.15(1.58)$ & $6.23(2.55)$ & $21.61(3.83)$ & $7.21(3.43)$ & $6.44(3.03)$ \\
\hline \multirow[t]{2}{*}{ HPC_W (CFU/mL) } & $2.1 \times 10^{3}-3.2 \times 10^{5}(21)$ & $3.1 \times 10^{4}-2.2 \times 10^{6}(7)$ & $9.3 \times 10^{3}-9.9 \times 10^{5}(22)$ & $2.7 \times 10^{4}-2.5 \times 10^{7}(42)$ & $5.0 \times 10^{3}-7.1 \times 10^{5}(21)$ & $4.5 \times 10^{3}-2.4 \times 10^{6}(20)$ \\
\hline & $6.5 \times 10^{4}\left(8.9 \times 10^{4}\right)$ & $3.7 \times 10^{5}\left(8.2 \times 10^{5}\right)$ & $2.6 \times 10^{5}\left(2.9 \times 10^{5}\right)$ & $1.2 \times 10^{6}\left(3.8 \times 10^{6}\right)$ & $1.3 \times 10^{5}\left(1.6 \times 10^{5}\right)$ & $2.3 \times 10^{5}\left(5.1 \times 10^{5}\right)$ \\
\hline \multirow[t]{2}{*}{ DNA_W (cells/mL) } & $5.7 \times 10^{4}-6.8 \times 10^{8}(21)$ & $1.1 \times 10^{7}-1.1 \times 10^{9}(7)$ & $8.3 \times 10^{4}-6.4 \times 10^{8}(22)$ & $4.5 \times 10^{7}-1.4 \times 10^{10}(42)$ & $5.0 \times 10^{4}-1.6 \times 10^{8}(21)$ & $1.2 \times 10^{7}-9.6 \times 10^{8}(20)$ \\
\hline & $1.9 \times 10^{8}\left(2.2 \times 10^{8}\right)$ & $2.0 \times 10^{8}\left(3.9 \times 10^{8}\right)$ & $8.3 \times 10^{7}\left(1.5 \times 10^{8}\right)$ & $2.0 \times 10^{9}\left(3.5 \times 10^{9}\right)$ & $4.4 \times 10^{7}\left(5.0 \times 10^{7}\right)$ & $2.9 \times 10^{8}\left(2.6 \times 10^{8}\right)$ \\
\hline
\end{tabular}

\footnotetext{
* Range (n)

** Mean (SD)
} 

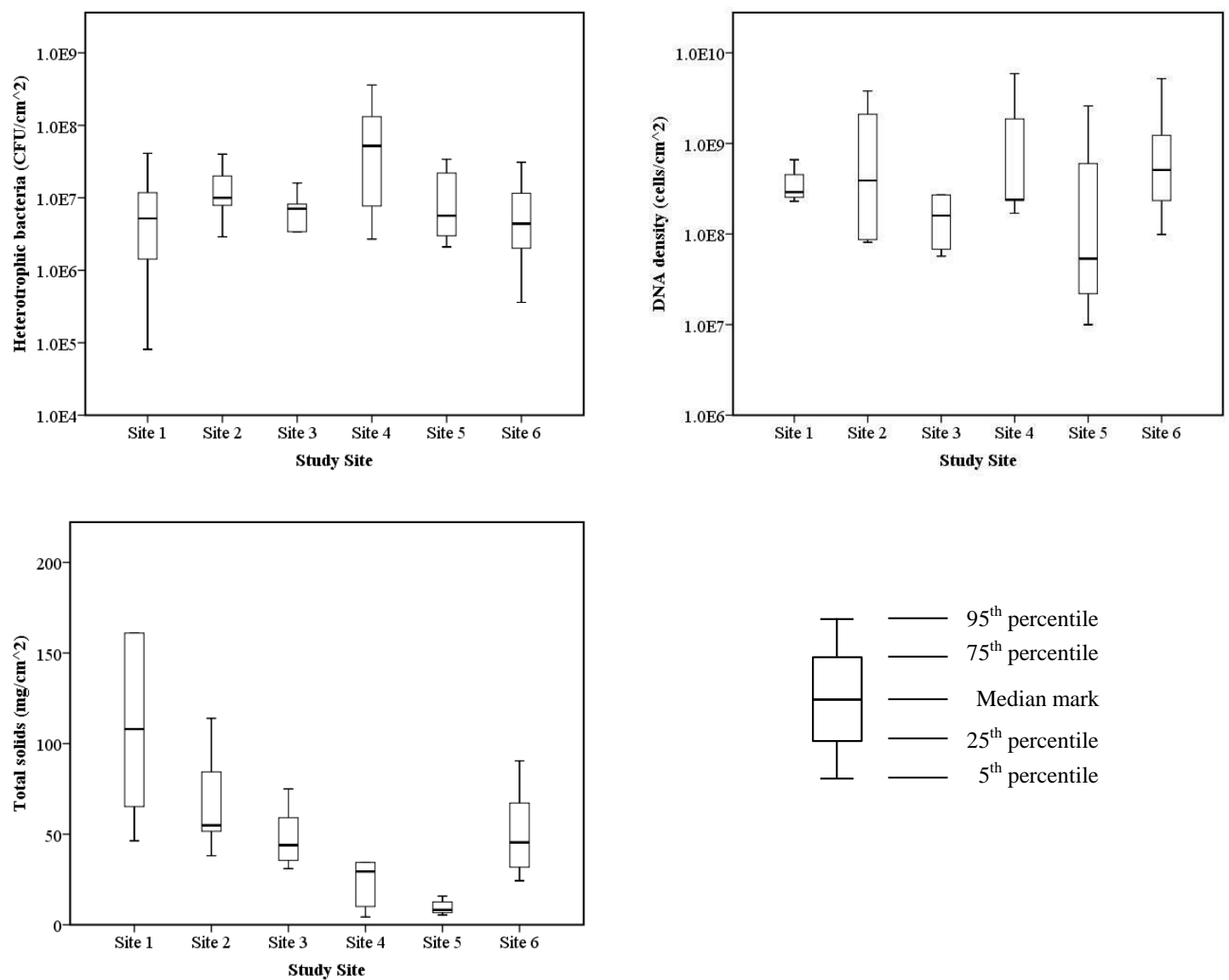

Fig. 2 Box plots showing the spatial variation of sediment bed quality parameters of HPC_S, DNA_S and TS.

In Japan, the most stringent effluent standard of gappei-shori johkasou (advanced johkasou) is set at BOD $10 \mathrm{mg} / \mathrm{L}, \mathrm{TN} 10 \mathrm{mg} / \mathrm{L}$ and TP $1 \mathrm{mg} / \mathrm{L}^{11)}$. The average concentration of BOD, TN and TP at Site 4 were $11.66,17.38$ and $2.08 \mathrm{mg} / \mathrm{L}$, respectively. If compared to the designated standard values in the Environmental Quality Standards for Conservation of the Living Environment for rivers and lakes ${ }^{29)}$, the average values of BOD, TN and TP are significantly higher. This thus suggests the need for further improvement of the johkasou performance in treating household wastewater or some approaches taken in the channels (such as occasional flushing of the channels with river water, underground water or stored rain water, packing materials that can remove the pollutants remaining in the effluent from johkasou).

\section{(3) Principal component analysis}

PCA was performed to identify the characteristics of water quality variables in all studied sites based on the data set obtained from temporal monitoring during the study period. The Scree plot shown in Fig. 4 showed a pronounced change of slope after the second eigenvalue. Cattel and Jaspers (1967) and Vega et al. (1998) suggested using all the PCs up to and including the first one after the brake ${ }^{27,30)}$. In this study, three PCs were retained, which could explain $85.18 \%$ of the variance of information contained in the original data set.

A rotation of principal components can achieve a simpler and more meaningful representation of the underlying factors by decreasing the contribution PCs to variables with minor significance and increasing the more significant ones. Rotation produces a new set of factors, each factor involving primarily a subset of the original variables with as little overlap as possible, so that the original variables are divided into groups somewhat independent of each other ${ }^{27}$. Eigenvalues and loadings of these varifactors are displayed in Table 3 and a planar plot of the eighteen variables is shown in Fig. 5. 

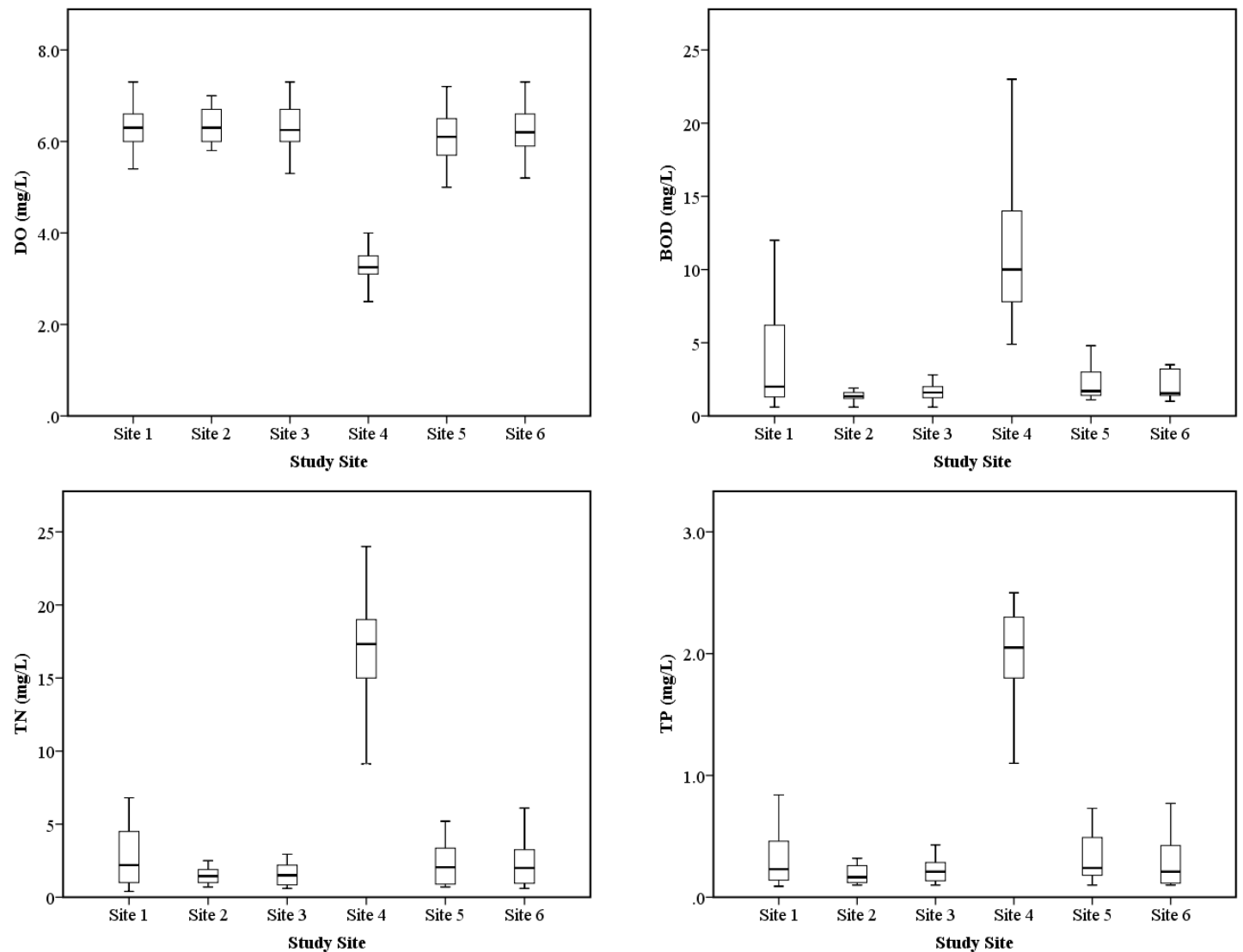

Fig. 3 Box plots showing the spatial variation of physicochemical water quality parameters of DO, BOD, TN and TP.

The first factor (PC1) accounted for $56.79 \%$ of the total variance and was positively and strongly contributed by nutrient related parameters TP and TN, the organic carbon related parameters BOD and UV260, the inorganic chloride ion, mineral related parameter EC and the microbial parameter DNA_W; and was negatively affected by DO and flow rate. The

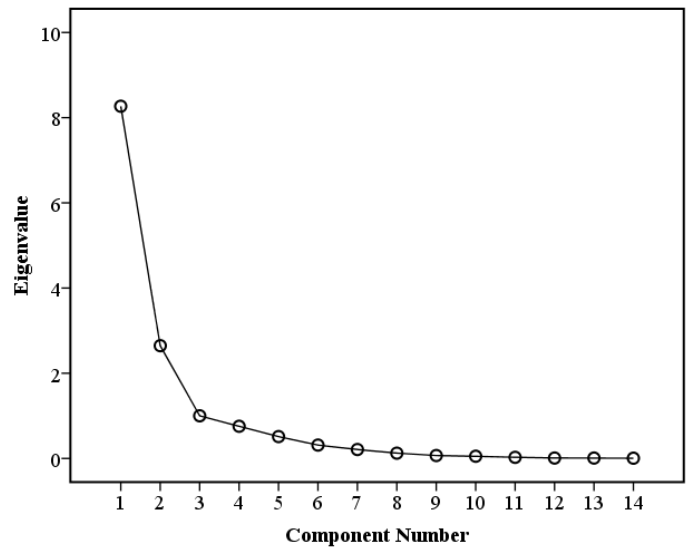

Fig. 4 Scree plot of the characteristic roots (eigenvalues) of components. negative factor loading of DO suggests the consumption of DO for degradation of organic matter by bacteria.

The second factor (PC2), which accounted for $19.01 \%$ of the total variance, had a strong positive relation with Temp, SS and ORP but was negatively affected by $\mathrm{pH}$.

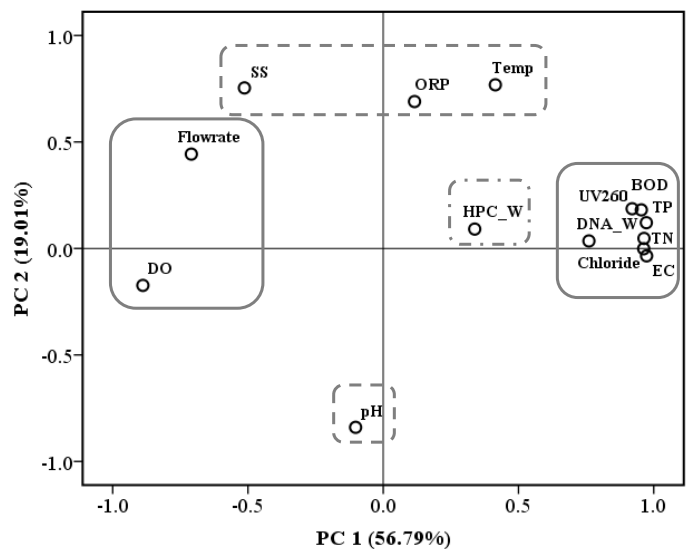

Fig. 5 Scores of variables on the bi-dimensional plane for the principal components $\mathrm{PC} 1$ and $\mathrm{PC} 2$. 
Table 3. Loadings of 14 variables on the three rotated ${ }^{\text {a) }}$ principal components for all data sets of six sampling sites

\begin{tabular}{lccr}
\hline \multirow{2}{*}{ Variable } & \multicolumn{3}{c}{ Component } \\
\cline { 2 - 4 } & PC 1 & PC 2 & PC 3 \\
\hline Flowrate & $\mathbf{- 0 . 7 0 9}$ & 0.443 & -0.384 \\
pH & -0.102 & $\mathbf{- 0 . 8 4 0}$ & -0.153 \\
Temp & 0.414 & $\mathbf{0 . 7 6 8}$ & -0.238 \\
ORP & 0.116 & $\mathbf{0 . 6 9 0}$ & 0.135 \\
EC & $\mathbf{0 . 9 7 3}$ & -0.035 & 0.184 \\
UV260 & $\mathbf{0 . 9 5 4}$ & 0.181 & 0.101 \\
SS & -0.513 & $\mathbf{0 . 7 5 4}$ & -0.173 \\
DO & $\mathbf{- 0 . 8 8 9}$ & -0.173 & -0.222 \\
BOD & $\mathbf{0 . 9 2 0}$ & 0.187 & 0.235 \\
TN & $\mathbf{0 . 9 6 4}$ & 0.047 & 0.143 \\
TP & $\mathbf{0 . 9 7 3}$ & 0.121 & 0.127 \\
Chloride & $\mathbf{0 . 9 6 3}$ & -0.001 & 0.197 \\
HPC_W & 0.338 & 0.091 & $\mathbf{0 . 8 0 2}$ \\
DNA_W & $\mathbf{0 . 7 6 0}$ & 0.035 & -0.401 \\
\hline Eigenvalue & 7.951 & 2.662 & 1.304 \\
\% Variance explained & 56.79 & 19.01 & 9.31 \\
\% Cum. Variance & 56.79 & 75.81 & 85.12 \\
\hline Extraction Method: Pripcip
\end{tabular}

Extraction Method: Principal Component Analysis.

Rotation Method: Varimax with Kaiser Normalization.

a. Rotation converged in 5 iterations.

The third factor (PC3), accounting for $9.31 \%$ of the total variance, was strongly loaded by HPC_W, implying a potential impact of sediment on water phase parameters. Previous studies have indicated that resuspension of microbes from sediment can be a major source for the water column ${ }^{31}$.

By using PCA, the 14 original parameters were reduced to 3 key independent factors (Table 3). Each factor significantly related to specific parameters representing a different dimension of the water ${ }^{31)}$.

\section{(4) Cluster analysis}

Multivariate cluster analysis was applied to classify the sampling sites for all three significant factors obtained by PCA. Three dendrograms produced for these factors are shown in Fig. 6, 7 and 8 , respectively.

First factor. For factor 1, 6 sampling sites were divided into 3 clusters (Fig. 6). Cluster 1, including 4 sites, are located in the upstream and downstream of the channel combinedly influenced by johkasou effluent, underground water and paddy field runoff, and presented lower concentrations of EC, UV260, BOD, TN, TP and Chloride; and lower concentration of DO as compared to Site 4 .

Cluster 2 consists of Site 2 that is affected by underground water, gappei-shori johkasou effluent and water from Site 1. This site showed the lowest values for all water parameters except for DO. Cluster 3, which consists of only Site 4 that receives only effluent from gappei-shori johkasou, associated with the highest organic, mineral, nutrient, and microbial concentrations and the lowest $\mathrm{DO}$ value than other clusters.

Second factor. Based on the second factor dataset (Temp, SS, ORP and $\mathrm{pH}$ ), all 6 sites were classified into 3 clusters (Fig. 7). Cluster 1 includes Site 1, 2, 3 and 5 , all affected by johkasou effluent, underground water and paddy field runoff, and presented the relatively lower values of ORP and higher values of SS. Cluster 2 consists of Site 4 revealing the highest ORP and the lowest SS values. Cluster 3, which yielded the moderate values of ORP and SS as compared with others, is consisted of Site 6 .

Third factor. A plot of cluster analysis based on the third factor dataset (HPC_W subset) is presented in Fig. 8. Sites combinedly influenced by johkasou effluent, groundwater and paddy field runoff are grouped in

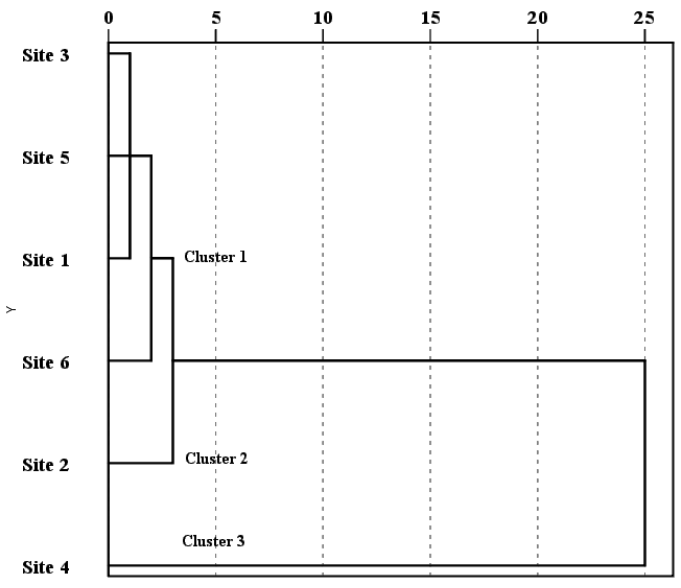

Fig. 6 Dendrogram of hierarchical cluster analysis for PC1 dataset (organic matter, nutrients, minerals and bacterial density).

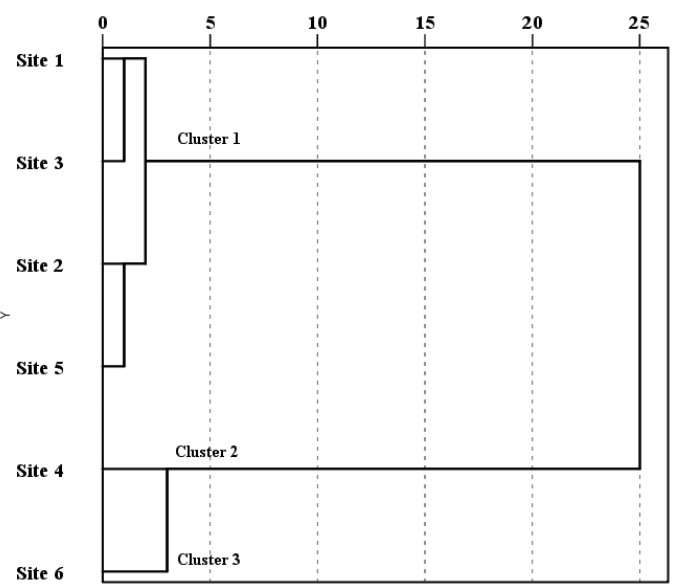

Fig. 7 Dendrogram of hierarchical cluster analysis for PC2 dataset (Temp, SS, ORP and $\mathrm{pH}$ ). 


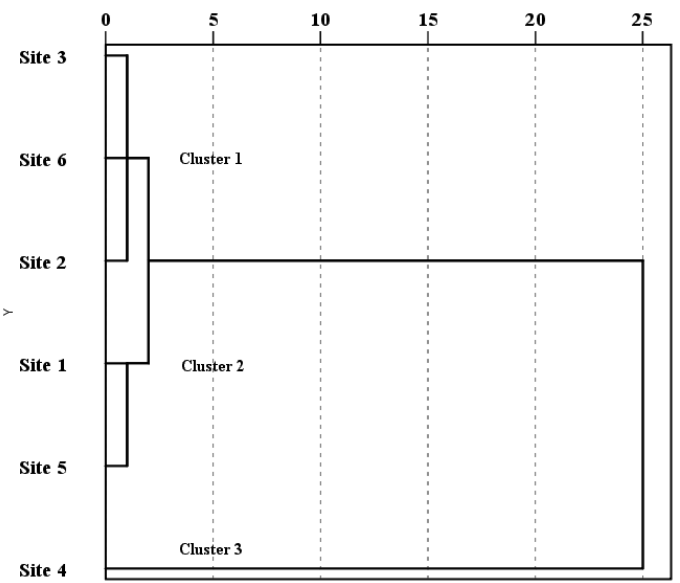

Fig. 8 Dendrogram of hierarchical cluster analysis for PC3 dataset (HPC_W).

Cluster 1 with the moderate concentrations of HPC_W. Group 2 consists of Site 1 and Site 5 and associated with the lower bacterial concentrations. For Cluster 3, however, only Site 4 exists, which had much higher concentrations of HPC_W.

\section{(6) Correlation analysis}

To find the relationship between sediment bed bacterial density and water quality parameter, correlation analysis was performed. As shown in Table 4, heterotrophic bacteria in the sediment phase (HPC_S) has statistically significant positive relations with BOD, TN, TP, Chloride ion and DNA_W $(r=0.588,0.307,0.618,0.533$ and 0.520 , with $p<0.01,<0.05,<0.01,<0.05$ and $<0.01$, respectively); and significantly negative correlations with flow rate, $\mathrm{pH}$ and $\mathrm{DO}(r=-0.438,-0.417$ and -0.386 with $p<0.05,<0.01$ and $<0.05$, respectively).

Table 4. Correlation coefficients of sediment bed bacterial density with water quality parameters

\begin{tabular}{|c|c|c|c|c|}
\hline Parameter & \multicolumn{2}{|c|}{ HPC_S } & \multicolumn{2}{|c|}{ DNA_S } \\
\hline Flow rate & -.438 & $*$ & -.285 & \\
\hline $\mathrm{pH}$ & -.417 & $* *$ & -.416 & $* *$ \\
\hline Temp & .200 & & -.048 & \\
\hline ORP & .231 & & -.089 & \\
\hline $\mathrm{EC}$ & .251 & & .208 & \\
\hline UV260 & .194 & & .523 & $* *$ \\
\hline SS & -.007 & & -.087 & \\
\hline DO & -.386 & $*$ & -.238 & \\
\hline BOD & .588 & $* *$ & .349 & \\
\hline $\mathrm{TN}$ & .307 & $*$ & .298 & \\
\hline $\mathrm{TP}$ & .618 & $* *$ & .270 & \\
\hline Chloride & .533 & $*$ & .236 & \\
\hline HPC_W & .125 & & .127 & \\
\hline DNA_W & .520 & $* *$ & .387 & $*$ \\
\hline
\end{tabular}

Previous studies have also shown that water flow over the sediment can affect the vertical diffusive flux of solutes, e.g. DO, COD, BOD, TN or TP because the solute concentration profile near the sediment/water interface varies with the flow velocity ${ }^{32)}$.

On the other hand, the DNA-based total bacteria in sediment DNA_S had positive correlation with the total bacteria in water DNA_W $(0.387$ with $p<0.05)$ and a negative correlation with $\mathrm{pH}(r=-0.416$, $p<0.01)$. As suggested by Rehmann and Soupir (2005), resuspension of microbes from the sediment bed can be a major source for the stream water ${ }^{33)}$.

\section{(7) Sediment bacterial community structure analysis}

The PCR-DGGE pattern is displayed in Fig. 9. For sediment bacteria at Site 4, totally 26 bright bands were detected (weak band were discarded). Comparison with the bands of other sites revealed similarity in the bacterial population among the sites. However, there were several band positions found unique for some sites.

The obtained DGGE patterns were compared with one another by pairwise similarity coefficients of Dice $(S)$, which were determined in the range 0.51-1.00 through analysis with Quantity One 4.3.0. It can be seen from Fig. 10 that Site 5 and Site 6 were positioned in one cluster, indicating their strong similarity (Dice coefficient is 0.86 ). Their similarity in the quality of water might be the reason responsible since both sites are located in the downstream of the channel investigated in this study.

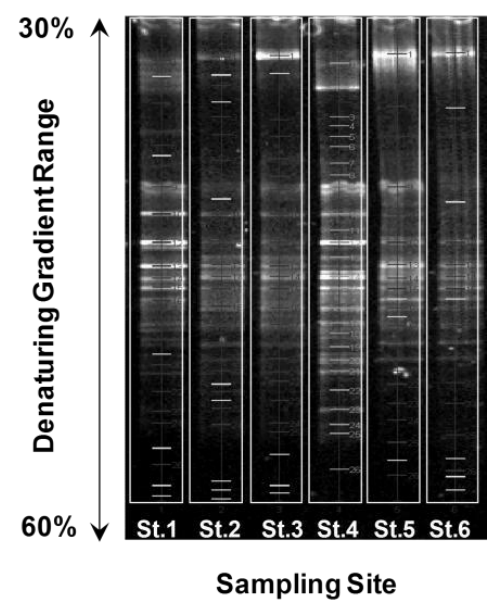

Fig. 9 DGGE band patterns of 16S rDNA amplified using the total genomic DNA extracted from sediment collected from six sites in November 2010. 


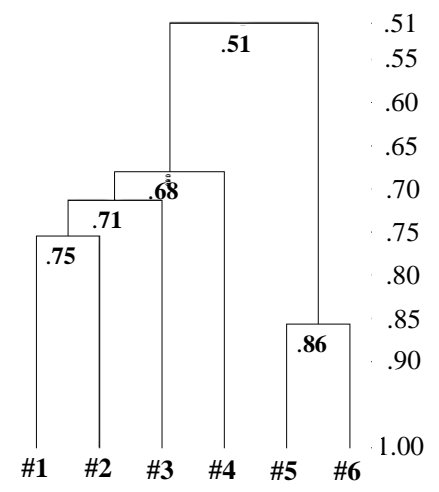

Fig. 10 Cluster analysis of DGGE band patterns for six study sites.

The patterns at Site 1, 2, 3 and 4 were also similar (S value, 0.68), which may suggest the effect of water quality on the sediment bacterial community, and the interactions between both are similar for all these 4 sites.

\section{CONCLUSIONS}

In this study, the formation of bacterial community in the sediment bed of open channels receiving johkasou effluent in a residential area was investigated and its likely relations with water quality were discussed. Varifactors obtained from the principal component / factor analysis indicated that parameters related to organic / nutrient content had comparatively stronger relations with the density of sediment bacteria. The site receiving only the effluent from johkasou revealed water quality much worse than other sites receiving also underground water and water from paddy fields surrounding the studied area, particularly for BOD, TN, TP and DO. Hierarchical cluster analysis grouped 6 study sites into three clusters based on the measured values of water quality parameters. The results of correlation analysis suggested the sediment bed bacterial density had statistically significant relations with water quality parameters. Cluster analysis of the PCR-DGGE patterns obtained for all 6 sites revealed the existence of differences among the sites in the structure of bacterial community populated in the sediment bed of the channels.

Although detailed investigation of likely interactions between water and sediment in the channels is needed and better interpreting the results obtained in the study needs investigation of the bacterial sources inside and directly discharged from johkasou and in surrounding environments (including paddy fields), the findings obtained through the present study are considered to be of greater significance since they can be used as the first hand reference materials for taking measures for improving channel water quality and hence the living environment of many residential areas that use johkasou.

\section{REFERENCES}

1) Yang, X.M., Morita, A., Nakano, I., Kushida, Y. and Ogawa, H.: History and current situation of night soil treatment systems and decentralized wastewater treatment systems in Japan, Water Practice and Technology, doi: 10.2166/WPT.2010.096, 2010.

2) JECES (Japan Education Center of Environmental Sanitation). See http://www.jeces.or.jp/en/database/index.html

3) Lick, W.: Contaminant transport in surface waters, CRC Press, Boca Raton, FL, 2009.

4) Watanabe, T., Kuniyasu, K. and Ohmori H.: Anaerobic and aerobic submerged bio-filter system for small scale on-site domestic sewage treatment, Water Science and Technology, Vol. 27, No. 1, pp. 51-57, 1993.

5) Imura, M., Sato, Y., Inamori, Y. and Sudo, R.: Development of a high-efficiency household biofilm reactor, Water Science and Technology, Vol. 31, No. 9, pp. 163-171, 1995.

6) Inamori, Y., Takai, T., Yamamoto, Y., Katagai, N., Sankai, T. and Hirata, A.: Sludge production characteristics of small scale wastewater treatment facilities using anaerobic/aerobic biofilm reactors, Water Science and Technology, Vol. 34, No. 3-4, pp. 379-387, 1996.

7) Nakajima, J., Fujimura, Y. and Inamori, Y.: Performance evaluation of on-site treatment facilities for wastewater from households, hotels and restaurants, Water Science and Technology, Vol. 39, No. 8, pp. 85-92, 1999.

8) Kaneko, M., Nambu, T. and Tokoro, M.: Behaviour of pathogenic E. coli and Salmonella enteritidis in small domestic sewage treatment apparatus (johkasou), Water Science and Technology, Vol. 43, No. 12, pp. 191-193, 2001.

9) Ohmori, H., Yahashi, T., Furukawa, Y., Kawamura, K. and Yamamoto, Y.: Treatment performance of newly developed johkasous with membrane separation, Water Science and Technology, Vol. 41, No. 10-11, pp. 197-204, 2000.

10) Ebie, Y., Matsumura, M., Noda, N., Tsuneda, S., Hirata, A. and Inamori, Y.: Community analysis of nitrifying bacteria in an advanced and compact Gappei-Johkasou by FISH and PCR-DGGE, Water Science and Technology, Vol. 46, No. 11-12, pp. 105-111, 2002.

11) Nakagawa, G., Ebie, Y., Tsuneda, S., Matsumura, M. and Inamori, Y.: Use of real-time PCR to examine the relationship between ammonia oxidizing bacterial populations and nitrogen removal efficiency in a small decentralized treatment system 'Johkasou', Water Science and Technology, Vol. 55, No. 7, pp. 203-210, 2007.

12) Ebie, Y., Kondo, T., Kadoya, N., Mouri, M., Moruyama, O., Noritake, S. ,Inamori, Y. and $\mathrm{Xu}, \mathrm{K}$ : Recovery oriented phosphorus adsorption process in decentralized advanced Johkasou, Water Science and Technology, Vol. 57, No. 12, pp. 1977-1981, 2008.

13) Yu, K.C., Ho, S.T., Chang, J.K. and Lai, S.D.: Multivariate correlation of water quality, sediment and benthic bio-community components in Ell-Ren river system, Taiwan, Water, Air and Soil Pollution, Vol. 84, pp. 31-49, 1995.

14) APHA, AWWA and WEF: Standard Methods for the examination of water and wastewater, 21st edn., American Public Health Association, American Water Work Association, Water Environment Federation, USA, 2005. 
15) Zhou W., Kageyama K., Li, F. \& Yuasa A.: Monitoring of microbiological water quality by real-time PCR, Environmental Technology, Vol. 28, No. 5, pp. 545-553, 2007.

16) Nadkarni, M.A., Martin, F.E., Jacques, N.A. and Hunter, N.: Determination of bacterial load by real-time PCR using broad-range (universal) probe and primers set, Microbiology, Vol. 148, pp. 257-266, 2002.

17) Dolezel, J., Bartos, J., Voglmayr, H. and Greilhuber, J.: Nuclear DNA content and genome size of trout and human, Letter to the editor, Cytometry Part A, Vol. 51A, pp. 127-128, 2003.

18) Harata, N., Li, F., Ito, M., Katamine, Y. and Yoshimura, C.: Evaluation of the density of microorganisms in Nagara River water system by plate culture and real time PCR methods, Environmental Engineering Research, Vol. 45, pp. 407-414, 2008 (in Japanese).

19) Stach, J.E.M., Bathe, S., Clapp, J.P. and Burns, G.: PCR-SSCP comparison of 16 rDNA sequence diversity in soil DNA obtained using different isolation and purification methods, FEMS Microbiology Ecology, Vol. 36, pp. 139-151.

20) Muyzer, G., Hottentraeger, S., Teske A. and Wawer, C.: Denaturing gradient gel electrophoresis of PCR amplified $16 \mathrm{~S}$ rDNA - A new molecular approach to analyze the genetic diversity of mixed microbial communities. In: Molecular Microbial Ecology Manual. Kluwer Academic Publishers, the Nederlands, pp. 1-23, 1996.

21) Ferris, M.J., Muyzer, G. and Ward, D.M.: Denaturing gradient gel electrophoresis profiles of 16S rRNA defined populations inhabiting a hot spring microbial mat community, Appl Environ Microbiol, Vol. 62, pp. 340-346, 1996.

22) Casamayor, E.O, Schafer, H., Baneras L., Pedros-Alio, C., and Muyzer, G.: Identification and spatiotemporal difference between microbial assemblages from two neighboring sulfurous lakes: comparison by microscopy and denaturing gradient gel electrophoresis, Appl Environ Microbiol, Vol. 66, pp. 499-508, 2000.

23) Zhao, X., Yang, L., Yu, Z., Peng, N., Xiao, L., Yin, D. and Qin, B.: Characterization of depth-related microbial communities in lake sediment by denaturing gradient gel electrophoresis of amplified 16S rRNA fragments, Journal of
Environmental Sciences, Vol. 20, pp. 224-230, 2008.

24) Japan Sewage Works Association (JSWA), Method for the Examination of Sewage. Yoshida Press, Tokyo, Japan, 1997. (in Japanese).

25) Shrestha, S. and Kazama, F.: Assessment of surface water quality using multivariate statistical techniques: A case study of the Fuji river basin, Japan, Environ. Mode. Softw., Vol. 22, No. 4, pp. 464-475, 2007.

26) Helena, B., Pardo, R., Vega, M., Barrado, E., Fernández, J. M., Fernández, L.: Temporal evolution of groundwater composition in an alluvial aquifer (Pisuerga River, Spain) by principal component analysis, Water Res., Vol. 34, No. 3, pp. 807-816, 2000.

27) Vega, M., Pardo, R., Barrado, E., and Deban, L.: Assessment of seasonal and polluting effects on the quality of river water by exploratory data analysis, Water Res., Vol. 32, No. 12, pp. 3581- 3592, 1998.

28) Moura, A., Tacao, M., Hendriques, I., Dias, J., Ferreira, P. and Correia, A.: Characterization of bacterial diversity in two aerated lagoons of a wastewater treatment plant using PCR-DGGE analysis, Microbial Research, Vol. 164, pp. 560-569, 2009.

29) Ministry of the Environment, Government of Japan: Environmental quality standards for water pollution, http://www.env.go.jp/en/water/wq/wp.pdf, Accessed 11 April 2012.

30) Catell, R.B. and Jasper, J.: A general plasmode (no. 30-10-5-2) for factor analytic exercises and research, Mult. Behav. Res. Monogr., Vol. 67, pp. 1-212, 1967.

31) Wang, X.L., Lu, Y.L., Han, J.Y., He, G.Z., Wang, T.Y.: Identification of anthropogenic influences on water quality of rivers in Taihu watershed. Journal of Environmental Science, Vol. 19, pp. 475-481, 2007.

32) Higashino, M. and Stefan, H.G.: Sedimentary microbial oxygen demand for laminar flow over a sediment bed of finite length, Water Res., Vol. 39, pp. 3153-3166, 2005.

33) Rehman, C.R. and Soupir, M., L.: Importance of interactions between the water column and the sediment for microbial concentrations in streams, Water Res., Vol. 43, pp. 4579-4589, 2009.

(Received May 25, 2012) 